\title{
The Implementation of Gamification System in Higher Education Teaching
}

\author{
Case Study: Bina Nusantara University
}

\author{
Desman Hidayat \\ Binus Entrepreneurship Center \\ Bina Nusantara University \\ Jakarta, Indonesia \\ d4906@binus.ac.id
}

\begin{abstract}
Low level of in-class participation can be a problem for lecturers when they teach Asian students. One of the reason is the characteristics of the Asian students, which are quiet and passive. Active learning is needed to solve this problem. Gamification is one of the things that can improve active learning. This study aims to understand how to design gamification system for higher education teaching, the factors contributed to the gamification system in higher education, and the impacts of the gamification system for students with the case study of Bina Nusantara University in Indonesia. The finding shows that there are several things to consider in designing gamification system. Factors in the system, the lecturers, the course, and the students also take important parts in the implementation. When it is done correctly, there will be a lot of positive impacts for the students and the teaching
\end{abstract}

Keywords - gamification, higher education, teaching method

\section{INTRODUCTION}

Teaching in higher education can be challenging. One of the challenge is how to make students more active in the class. Students, especially Asian students, are not really active in the classroom. Asian students commonly have a low level of inclass participation [1]. It shows that this is a common problem in the classroom, especially in Asian countries. An observation has been made about Asian students, and showed a generalization about their characteristics, which are quiet and passive, dependent on lecturers, focused on grades, lack of awareness of plagiarism, and rewarding experience. [2] These characteristics is also shown by the Indonesian students.

Active learning is one of the techniques that can help the students in learning and be more active, therefore, solving the problems with Asian students. The active learning strategies can be defined as instructional activities that need students to do and think more about what they are doing, where they can involved more by read, write, discuss, or engaged in solving problems [3].

A study from AUB shows that active learning and class engagement in higher education can be improved by using gamification, because gamification is about engagement and enhanced learning [4]. By definition, gamification is using game-based mechanics, aesthetics, and game thinking to engage people, motivate action, promote learning, and solve problems [5].
Mapp, in his book [5], also defined 2 types of gamification, which are structural gamification and content gamification, where the structural gamification applies game elements to the structure around the content, while content gamification applies game elements to the content itself. This paper will use structural gamification to be implemented in the classroom, by using student's points, quests, and other gamification elements.

There are already several researches related to this work before, with various results. Jayasinghe \& Dharmaratne [6] who analyzed game based learning and gamification in higher education, conclude that students who use gamified learning materials, will automatically follow the learning process of Bloom Taxonomy. Dominquez, et.al. [7] concluded that gamification can be potential to increase student motivation. They also concluded that the gamification itself is not trivial to achieve that effect, and a big effort is required to design and implement the system for the students to be able to fully motivate them. Both researches were using computer-based platform as their media for gamification.

Hanus \& Fox [8] used a different approach by focusing more on the game mechanics for their research in gamification. Their results found that gamified course students showed less motivation, satisfaction, and empowerment over time than non-gamified class students.

This research is held at Bina Nusantara University in Indonesia. As a part of Asian students, the students at Bina Nusantara University also have a low level of in-class participation. The author will use gamification system to make the students more active in the class and to increase the discipline of the students.

This study aims to understand how gamification can be implemented for teaching in higher education. Several questions will be answered in this research:

1. How to design gamification system for higher education teaching?

2. What are the factors contributed to the gamification system implementation in higher education teaching? 3. What are the impacts of the gamification for students?

\section{METHODS}

There are 5 steps on how to apply gamification in education [9]: 
1. Understanding the target audience and the context

2. Defining learning objectives

3. Structuring the experience

4. Identifying resources

5. Applying gamification elements

These steps will be implemented in designing the gamification system:

\section{Understanding the target audience and the context}

First thing to know before designing the system, is to understand about the course that will be taught with gamification. The author teach entrepreneurship course in Bina Nusantara University in Indonesia. Entrepreneurship course is taught to all the majors in the university, but in this paper, the author will use the example for students who are majoring International Business Management. The class consists of three parts: seminars, classroom teaching, and business expo. There are 15-30 students in a class.

Gamification system is implemented for the author's classroom teaching. There are 7 sessions of the classroom teaching, so the system has to be built according to these sessions, in regards that the first session is used for introduction and explaining the rules for the gamification system. Evaluation of the scoring in the course itself is divided into assignment (35\%), mid exam (25\%), and final exam $(40 \%)$.

\section{Defining learning objectives} are:

The learning objectives can be divided into 2 parts, which

- Course objectives, which are related with the knowledge about entrepreneurship

- Classroom objectives, which are related with how to make students more active in the class, develop teamwork, develop leadership, make students more discipline, and make the class more fun.

\section{Structuring the experience}

a. Objective: Increase the knowledge about entrepreneurship How to complete: Students will be asked several questions about general knowledge, business, and the course materials.

b. Objective: Increase students' participation in the class

How to complete: Giving point everytime the students are active in the class, whether it is to ask, give opinion, or answer questions.

c. Objective: Develop teamwork

How to complete: Give the students some tasks that need to be done in team.

d. Objective: Develop leadership

How to complete: Give the students leadership roles, such as class prefect and team leaders.

e. Objective: Make the students more discipline

How to complete: Give the students points for several tasks related with discipline, such as being ontime.

f. Objective: Make the class more fun

How to complete: Use several gamification elements in the class.

4. Identifying resources
Following are several details of the resources:

- Tracking mechanism

To make it easier to show the students about leveling, the author use online spreadsheet (Figure 1).

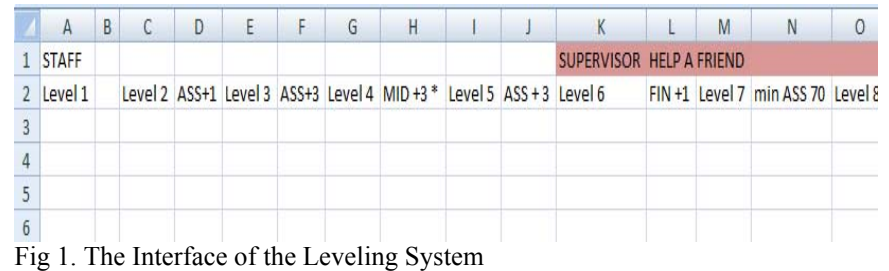

The students will be able to track their own level each week, and they will understand about their own progress by looking at the interface of the leveling system.

\section{- Currency}

The currency or the points in this gamification system is the assignment points of the students, which can be converted into additional final exam point when they have excess points after reaching full score of assignment.

- Level

There are no stage level that the author use in the gamification system, but every students have their own level, so they are competing with their own current level. There will also be several "quests" that they are able to achieve, which will be explained on the next section.

- Rules

There are several additional rules that will be used, beside the course rules themselves. Those rules will be explained on the next section.

- Feedback

When students fail to complete certain "quests", the lecturer will give them feedback on why they fail and their chance on completing the quests all over again.

\section{Applying gamification elements}

PBLs (Points, Badges, Leaderboards) are powerful, practical, and relevant elements to implement the gamification [10]. Each of these parts will be defined in the following:

(1) Points. Points are the things that connect the gamification system and the course scoring. The author can add extra assignment points according to the designed gamification system.

(2) Badges. It is related with the achievement or the status of the students themselves. The author has given each student his own status, which will change when the student moves up to a higher level position in the class.

(3) Leaderboard. Students can see their position in the class, although there are no specific position where students know they are the best in the class, but they will be able to see how they compare generally to other students in the class.

So, from the elements explained above, the author has designed several rules: 
(1) Each students have their own level. Everyone will start the class from level 1, and they will try to reach the highest level that they can, in this case, level 16.

(2) There are names for each part of the level that they reach. Level 1-5: staff, level 6-10: supervisor, level 11-15: manager, level 16: director. The author use this to simulate the office worker status, which are staff, supervisor, manager, and director.

(3) Each levels give the student extra bonus which keep on adding up according to their level. The author has made the leveling bonus as following (Table I):

\begin{tabular}{|c|c|c|c|}
\hline Level & Bonus & Status & Status Bonus \\
\hline 1 & Nothing & \multirow[t]{5}{*}{ Staff } & \\
\hline 2 & Assignment point +1 & & \\
\hline 3 & Assignment point +3 & & \\
\hline 4 & $\begin{array}{l}\text { Mid exam score }+3 \text { (if they are } \\
\text { able to reach level } 4 \text { before mid } \\
\text { exam) }\end{array}$ & & \\
\hline 5 & Assignment point +3 & & \\
\hline 6 & Final exam score +1 & \multirow[t]{5}{*}{ Supervisor } & $\begin{array}{l}\text { Help a friend } \\
\text { level up }\end{array}$ \\
\hline 7 & $\begin{array}{l}\text { Minimum assignment point }= \\
70\end{array}$ & & \\
\hline 8 & $\begin{array}{l}\text { Minimum assignment point }= \\
80\end{array}$ & & \\
\hline 9 & Final exam score +2 & & \\
\hline 10 & Final exam score +3 & & \\
\hline 11 & Minimum course grade B & \multirow[t]{2}{*}{ Manager } & $\begin{array}{l}\text { Help } 2 \text { friends } \\
\text { level up }\end{array}$ \\
\hline 12 & Assignment point $=100$ & & \\
\hline 13 & Minimum course grade $\mathrm{B}+$ & \multirow[t]{3}{*}{ Manager } & \\
\hline 14 & Minimum course grade A- & & \\
\hline 15 & Minimum course grade A & & \\
\hline 16 & $\begin{array}{l}\text { Assignment \& final exam score } \\
=100\end{array}$ & Director & \\
\hline
\end{tabular}

When the students raise their level status from staff to supervisor, and from supervisor to manager, they will get the opportunity to help a friend or two. It is to help their teamwork and empathy with other students.

To execute the planning, there are also the basic rules regarding that need to be followed to the course requirements themselves, which are: (a) Students must attend and fill in the final and mid exam. If they do not do it, then the score will be 0, no excuses. (b) Students must pass the attendance requirement, which saying that they can not skip the class for more than 1 time, or they will have a certain fail in the course.

(4). Beside the leveling bonus, students with higher level will get higher assignment point bonus everytime they are active in the class. Being active in the class can be done in a lot of form, such as active asking and answering questions. They will get the point according to their level. Level 1 student will get 1 assignment point when he is active, level 2 will get 2 assignment points, so level 15 will get 15 assignment points when he is active.

(5). To level up, students must be able to active the class. Everytime they are active, they will level up. For example, student level 4 is answering the lecturer's question, the he will get 4 assignment points and also level up to level 5 , which give him +3 to his assignment point according to the leveling bonus.

(6). In each session of the course, there will be several opportunities for the students to get some points.

(7). According to video games terminology, quest is a task that a player may complete in order to gain a reward [11]. To make the gamification system more interesting, the author as the lecturer also added several game quests and notes for students, divided into individual and team quests, as the following (Table II):

TABLE II. QUESTS

\begin{tabular}{|c|c|c|c|}
\hline $\begin{array}{l}\text { Types of } \\
\text { Quests }\end{array}$ & Quest Name & Bonus & Quest Details \\
\hline \multirow[t]{4}{*}{$\begin{array}{l}\text { Individual } \\
\text { Quests }\end{array}$} & $\begin{array}{l}\text { "Always } \\
\text { there" }\end{array}$ & Level up & $\begin{array}{l}\text { Never skipped any } \\
\text { class until the end } \\
\text { of the course }\end{array}$ \\
\hline & Prefect (1) & $\begin{array}{l}\text { Instant Level } 3+5 \\
\text { assignment points }\end{array}$ & $\begin{array}{l}\text { Be the class } \\
\text { prefect without } \\
\text { any vice prefect. } \\
\text { The prefect can } \\
\text { not be the same } \\
\text { person with the } \\
\text { team leader. }\end{array}$ \\
\hline & $\begin{array}{l}\text { Head Prefect } \\
\& \quad \text { Vice } \\
\text { Prefect (2) }\end{array}$ & $\begin{array}{l}\text { Both students get } \\
\text { instant level } 2+3 \\
\text { assignment points }\end{array}$ & $\begin{array}{l}\text { Be the head \& vice } \\
\text { prefect of the } \\
\text { class. Head \& vice } \\
\text { prefect can't be the } \\
\text { same person with } \\
\text { the team leader. }\end{array}$ \\
\hline & Team Leader & $\begin{array}{l}\text { Instant level } 2+1 \\
\text { assignment point }\end{array}$ & $\begin{array}{l}\text { Be the team } \\
\text { leader. Each class } \\
\text { will be divided itu } \\
4-5 \text { teams, so there } \\
\text { will be } 4-5 \text { team } \\
\text { leaders. }\end{array}$ \\
\hline \multirow[t]{5}{*}{ Team Quests } & Class Ontime & $\begin{array}{l}\text { Level up each of the } \\
\text { students } \\
\text { assignment point }\end{array}$ & $\begin{array}{l}\text { Every student } \\
\text { must come to the } \\
\text { class ontime. } \\
\text { Maximum } 3 \text { times. } \\
\text { If they are able to } \\
\text { do it more than } 3 \\
\text { times, then they } \\
\text { will only get }+1 \\
\text { assignment point } \\
\text { without leveling } \\
\text { up. }\end{array}$ \\
\hline & $\begin{array}{l}\text { Team Ontime } \\
3 \mathrm{x}\end{array}$ & \multirow[t]{4}{*}{$\begin{array}{l}\text { Each student in the } \\
\text { team will get a level } \\
\text { up according to } \\
\text { his/her current level }\end{array}$} & $\begin{array}{l}\text { Each student in the } \\
\text { team must come to } \\
\text { the class ontime } \\
\text { for } 3 \text { sessions. }\end{array}$ \\
\hline & $\begin{array}{l}\text { Team Ontime } \\
5 \mathrm{x}\end{array}$ & & $\begin{array}{l}\text { Each student in the } \\
\text { team must come to } \\
\text { the class ontime } \\
\text { for } 5 \text { sessions. }\end{array}$ \\
\hline & $\begin{array}{l}\text { Team Ontime } \\
6 \mathrm{x}\end{array}$ & & $\begin{array}{l}\text { Each student in the } \\
\text { team must come to } \\
\text { the class ontime } \\
\text { for } 6 \text { sessions. }\end{array}$ \\
\hline & $\begin{array}{l}\text { Team Ontime } \\
4 \text { times in a } \\
\text { row }\end{array}$ & & $\begin{array}{l}\text { Each student in the } \\
\text { team must come to } \\
\text { the class ontime } \\
\text { for } 4 \text { times in a } \\
\text { row. }\end{array}$ \\
\hline
\end{tabular}


(8). If the student assignment point summed up more than 100 points, then the extra points will go to the final exam point. The maximum assignment point for inactive student who is not actively seeking points will be 80 .

(9). These rules of gamification will be used in the class for the whole semester ( 7 sessions).

\section{THE IMPLEMETATION}

This gamification system will be implemented in 2 entrepreneurship classes for International Business Management major that is taught in the period of March 3rd, 2016 to June 2nd, 2016.

The research is a qualitative research. The tool that will be used for the analysis is in-depth interviews with the students as the respondents. The purpose of in-depth interview itself is to understand the experience from other people and the meaning they make of that experience [12].

The questions will be related with 4 aspects related with the gamification system implementation in the higher education teaching, which are (1) the system itself, (2) the lecturer, (3) the course, and (4) the students. Author would like to analyze the factors related to the implementation of the gamification system from the view of the respondents, in this case, students.

\section{RESUlts AND Discussions}

After implementing the gamification system in the classroom for around 3 months, the results of the students' level can be seen below (Figure 2 and Figure 3):

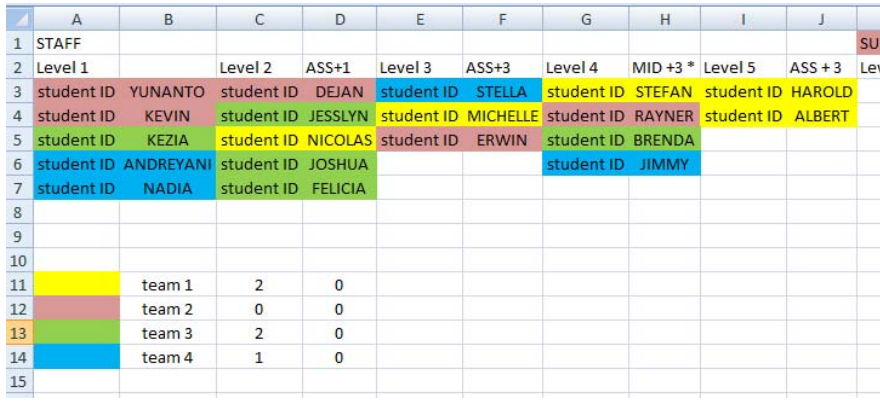

Fig 2. Leveling System Result for Class A

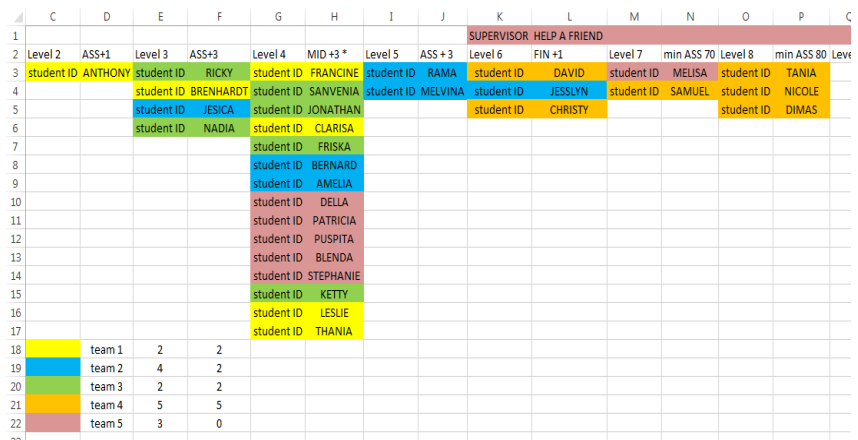

Fig 3. Leveling System Result for Class B
Notes:

1. The students' name that is used on figure 2 and 3 is disguised.

2. The colors show the team of students

3. The more they reached the right side, the higher their level will be.

4. First number beside the team name is the counter on which the team comes to the class ontime.

5. Second number beside the team name is the counter on which the team comes to the class ontime consecutively.

As we can see from the figures, class A consists of 19 students, while class B consists of 30 students. There is a contrast result between class A and class B. No one in class A is able to reach the status "supervisor" or level 6, while the maximum level reached in class B is level 8 . One of the reason for this result is because class A most of the time failed to be ontime.

After implementing gamification system in the classroom, the author evaluated the gamification system by having indepth interview with 7 students. Even 2 months after finishing the class, most of them students still remembered clearly about the gamification system, some even claimed that they remember it perfectly. Here are the findings from the interview:

1. Analysis about several aspects of the gamification system:

- The system

It is important for the lecturer to be able to explain the details of the gamification system. If the lecturer fails to do this, then the whole system won't be working well.

Individual quests, team quests, and the leveling system for each students are important for the gamification system. Each part will have positive impacts for the students.

Several things that students like the most about gamification system are the opportunity to gain points, helping friends, to be able to compete, and the appreciation for being active.

Some students doesn't like the subjective task, such as giving free level up to other friends, some students think that the duration for the gamification system ( 7 sessions), and most of them think that the system is not accomodating enough for introvert students.

All of the respondents said that the system motivated them to be present in the class for various reasons, such as helping friends to get a point from team ontime, and also because they want to get points by answering questions at the beginning of the class. Most students also think that the gamification system improved the way they study, although there are also study who didn't feel any changes, since the student is not active in the classroom.

Several suggestions were made for the gamification system, such as adding more analytical questions, more quests, find a way to help introverts to get points, and adding team battle features. 


\section{- The lecturers}

The characteristics of lecturers who are suited to use gamification system are lecturers who are creative, have a good communication skill, flexible and not too rigid, interactive, not too serious, have a good understanding on how to use technology, and willing to spend some time to prepare the system.

\section{- The courses}

This gamification system is suitable for some types of courses, which are courses that needs a lot of speaking, because it can make the students more active, courses that are serious and hard to understand, because it can help the students earn extra points. This is also related with the student characteristics mentioned in [2] which said that Asian students are generally focused on grade. By using gamification system, it is possible to turn this characteristics into something positive by making them more active.

\section{- The students}

In general, the current gamification system is not suitable for introvert students and also students who aren't interested in studying nor in the gamification system itself. It is helpful for students who are competitive, active, interested in learning the subjects, and also interested in passing the course with a good grade.

2. There are several positive impacts from the gamification, such as increasing the motivation and the discipline of the students (by giving more points when they can always attend the class and being ontime), making the class more fun, increase the mood and the knowledge as well, students become more active in the classroom, and reduce boredom. The system also helps students in developing their teamwork, leadership, and being responsible to their team.

\section{CONCLUSION}

Based on the analysis, there are several things to consider in designing gamification system for higher education teaching: (1) The rules and instructions of the system should be explained clearly in the beginning of the course. (2) The system should have points, student levels, and quests, to make it more interesting. (3) It is also important to accommodate passive students to help them earn some points.

The system needs to be designed to support students with all kind of characteristics. The lecturers should be creative and willing to spend times to design and implement the system. Gamification is suitable for courses that need students to be active, and for courses that are hard to understand. It is perfect when implemented to classes with active and competitive students who wants to learn seriously. These 4 factors need a serious attention when designing gamification system.

Gamification system will have a lot of positive impacts for the students themselves, for the classroom teaching, and also on how students build teamwork with other students.

Finally, for future research, it is suggested to design other implementation of the gamification system, test it with other segment of students, and then compare it with this system, to understand more about how the system works and how to improve the system.

\section{REFERENCES}

[1] M. Tani, "Quiet, but only in class : reviewing the in-class participation of Asian students," HERDSA Conf. 2005, vol. 5, p. 2007, 2005

[2] S.-H. Chuah, "Teaching East-Asian Students: Some Observations," High. Educ. Acad. Econ. Netw., 2010.

[3] C. C. Bonwell and J. A. Eison, Active Learning: Creating Excitement in the Classroom. ERIC Clearinghouse on Higher Education, The George Washington University, One Dupont Circle, Suite 630, Washington, DC 20036-1183, 1991.

[4] A. A. Arzoumanian, "AUB study: Gamification improves active learning and class engagement in higher education," 2015. [Online]. Available: http://www.aub.edu.lb/news/2015/Pages/gamificationhighered.aspx. [Accessed: 22-Aug-2016].

[5] K. M. Mapp, The Gamification of Learning and Instruction: Gamebased Methods and Strategies for Training and Education. San Francisco: Pfeiffer, 2012.

[6] U. Jayasinghe and A. Dharmaratne, "Game based learning vs. gamification from the higher education students' perspective," Int. Conf. Teaching, Assestment Learn. Eng., no. August, pp. 683-688, 2013.

[7] A. Domínguez, J. Saenz-De-Navarrete, L. De-Marcos, L. FernándezSanz, C. Pagés, and J. J. Martínez-Herráiz, "Gamifying learning experiences: Practical implications and outcomes," Comput. Educ., vol. 63, pp. 380-392, 2013.

[8] M. D. Hanus and J. Fox, "Assessing the effects of gamification in the classroom: A longitudinal study on intrinsic motivation, social comparison, satisfaction, effort, and academic performance," Comput. Educ., vol. 80, pp. 152-161, 2015.

[9] W. H. Huang and D. Soman, "Gamification Of Education," Res. Rep. Ser. Behav. Econ. Action., pp. 1-29, 2013.

[10] K. Werbach and D. Hunter, For the win: How game thinking can revolutionize your business. Wharton Digital Press, 2012.

[11] M. Siwkowski, "Gamification," 2016. [Online]. Available: http://konferencje.frse.org.pl/img/default/Mfile/file/2092/gamification m_siwkowski.pdf. [Accessed: 07-Aug-2016].

[12] B. Dicicco-Bloom and B. F. Crabtree, "The qualitative research interview.," Med. Educ., vol. 40, no. 4, pp. 314-21, Apr. 2006. 